\title{
Promoter Methylation Status of the Retinoic Acid Receptor-Beta 2 Gene in Breast Cancer Patients: A Case Control Study and Systematic Review
}

\author{
Kheirollah Yari ${ }^{a} \quad$ Zohreh Rahimi ${ }^{a}$ b \\ ${ }^{a}$ Medical Biology Research Center and ${ }^{b}$ Department of Clinical Biochemistry, Kermanshah University of \\ Medical Sciences, Kermanshah, Iran
}

Keywords

Breast cancer $\cdot$ RARß2 - Hypermethylation · Epigenetic · MSP · Iranian population

\begin{abstract}
Background: We aimed to determine the promoter methylation status of the retinoic acid receptor-beta 2 (RARß2) gene among breast cancer patients and to review relevant studies in this field in various populations. Methods: We analyzed 400 samples which comprised blood specimens from 102 breast cancer patients, 102 first-degree female relatives of patients, 100 cancer-free females, 48 breast cancer tissues, and 48 adjacent normal breast tissues from the same patients. The RARB2 methylation status was determined using methylation-specific polymerase chain reaction (MSP) and DNA sequencing methods. Results: The presence of combined partially methylated (MU) and fully methylated (MM) forms of the RARR2 gene (MU+MM) in the blood of patients was associated with susceptibility to breast cancer (odds ratio $=4.7, p=0.05)$. A significantly higher frequency of the MM genotype was observed in cancer tissue (10.4\%) compared to matched adjacent normal breast tissue $(0 \%)(p=0.02)$. Conclusion: We found a higher frequency of RARB2 gene methylation in the blood and cancer tissues of patients compared to the blood of controls and adjacent normal breast tissues. The survey of studies on various populations demonstrated a higher $R A R \beta 2$ methylation frequency in breast cancer patients compared to normal individuals, and many reports suggest a significant association between hypermethylation of the gene and susceptibility to breast cancer.
\end{abstract}

\section{Introduction}

Breast cancer is a heterogeneous malignancy in women associated with high morbidity and mortality $[1,2]$. Due to the considerably increased incidence rate of breast cancer, it could be considered as one of the most common health problems across different populations $[3,4]$. In developing countries including Iran, patients diagnosed with breast cancer are 10 years younger compared to those in developed countries [3]. Both genetic and epigenetic changes are involved in the individual susceptibility to breast cancer [5]. Epigenetic modifications alter gene expression through DNA hypermethylation, histone modification, and microRNA mechanisms [6]. In tumor cells, hypermethylation of $\mathrm{CpG}$ islands of tumorrelated genes can effectively inactivate the gene, whereas in normal cells, CpG islands are not methylated which may lead to gene transcription [7].

Retinoic acid (RA) as a main signaling biomolecule derived from vitamin $\mathrm{A}$ is implicated in the control of main developmental processes such as differentiation and cell growth. Based on antiproliferative and differentiation effects of retinoids, RA is considered as the suppressor of cancer cell growth [7,8]. RA binds and activates 2 types of nuclear receptor heterodimers of the retinoic acid receptor (RAR) and the retinoid X receptor (RXR). Among them, the retinoic acid receptor-beta $2(\mathrm{RAR} \beta 2)$ has a critical role in the chemopreventive effects of retinoids. The tumor suppressor gene $R A R \beta 2$ is located on chromosome 3 p24 and its loss is associated with RA resistance [7, $8]$. 
Reduced expression of $R A R B 2$ by genetic or epigenetic mechanisms is linked to many human cancers such as cervical $[9,10]$, head and neck [11], non-small cell lung [12], prostate [13], bladder, brain, and breast cancers [4, 14-16]. Knowledge of the DNA methylation status in the promoter regions of some candidate genes such as RARB2 may be useful for early detection, prognosis, and drug response prediction in breast cancer patients $[6,17]$. The aim of the present study was to evaluate the methylation status of the $R A R \beta 2$ gene in the CpG islands of its promoter and to detect whether it is associated with the risk of breast cancer in an Iranian population with Kurdish ethnic background. Furthermore, we reviewed studies that have previously investigated the methylation status of $R A R \beta 2$ in breast cancer patients.

\section{Materials and Methods}

\section{Sample Collection}

In the present case-control study, 400 samples including blood specimens from 102 female patients with breast cancer, 102 firstdegree female relatives of patients (mother, sister, or daughter), 100 cancer-free females, 48 breast cancer tissues, and 48 adjacent normal breast tissues from the same patients were investigated. The study was approved by the Ethics Committee of Kermanshah University of Medical Sciences, Iran. All individuals agreed to participate in the study and signed informed consent in accordance with the principles of the Helsinki II declaration.

Genomic DNA Extraction

DNA was extracted from EDTA-treated whole blood and from paraffin-embedded tissue blocks using the phenol-chloroform method [21].

\section{Methylation-Specific Polymerase Chain Reaction}

The methylation status of $R A R \beta 2$ was detected using methylation-specific polymerase chain reaction (MSP) as previously described [4]. The specific band intensity of the MSP product (170 bp) was determined using TotalLab TL120 software (TotalLab Ltd., Newcastle upon Tyne, UK). Based on TotalLab TL120 software analysis, only bands with an intensity higher than 50,000 values were considered. 8 samples from patients that were identified as MM (fully methylated) or UU (unmethylated) genotypes using the MSP method were selected for DNA sequencing (Macrogen Inc., Seoul, South Korea).

\section{Statistical Analysis}

The significance of differences in the frequencies of genotypes between the 3 study groups and between breast cancer tissues and adjacent normal breast tissues was determined using the chi-square test. Odds ratios (OR) and 95\% confidence intervals (95\% CI) were measured using SPSS 16.0 software (IBM Corp., Armonk, NY, USA). Statistical significance was assumed at the $\mathrm{p}<0.05$ level $[1,18]$.

\section{Literature Study and Data Extraction}

We included all relevant studies published in the English language related to DNA methylation of the $R A R \beta 2$ gene in breast cancer patients, obtained from searching the databases MEDLINE/PubMed and Scopus up to March 2016. Using the keywords 'DNA methylation', ' $R A R B \beta 2$ ', and 'breast cancer', 21 eligible original articles were identified and included in the systematic review.

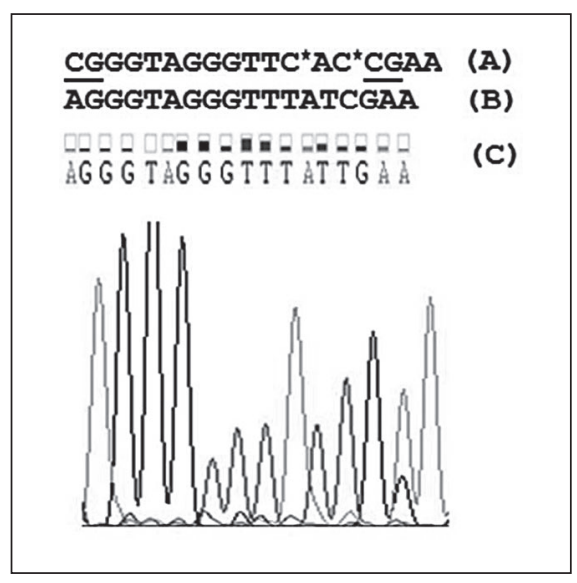

Fig. 1. Analysis of a fragment of the $R A R \beta 2$ gene in the promoter region using a DNA sequencing apparatus (Macrogen Inc., Seoul, South Korea). A Promoter sequence of the $R A R \beta 2$ gene in the NCBI database; $\boldsymbol{B}$ obtained sequences from MethPrimer software; C sequences obtained by DNA sequencing using a sodium bisulfite-treated sample. Underlined CG represents the CpG islands that have not been modified by sodium bisulfite treatment and remained intact as CG, whereas those $\mathrm{C}^{*}$ nucleotides that were not followed by a $\mathrm{G}$ nucleotide were modified to $\mathrm{T}$ after sodium bisulfite modification (B).

\section{Results}

The mean age of the patients was $49.8 \pm 10.3$ years (range $29-79$ years). 10 (10.2\%) and 28 (28.6\%) patients were aged below 30 and 40 years, respectively. The result of direct genomic DNA sequencing from 1 sample is shown in figure 1 . The frequencies of $R A R \beta 2$ combined methylated genotype (MU+MM) in the blood of patients, relatives of patients, and healthy individuals were 8.8, 2.9, and $2 \%$, respectively $\left(\chi^{2}=6.3, \mathrm{p}=0.042\right)$ (table 1$)$. The presence of $R A R \beta 2 \mathrm{MU}+\mathrm{MM}$ was associated with susceptibility to breast cancer $(\mathrm{OR}=4.7,95 \%$ CI $0.99-22.5, \mathrm{p}=$ 0.05 ) (table 1). A higher frequency of fully methylated $R A R \beta 2$ was observed in cancer tissue (10.4\%) compared to matched adjacent normal breast tissue $(0 \%)(\mathrm{p}=0.02)$ (table 2). As indicated in table 2, we did not detect the same frequency of $R A R \beta \mathrm{MU}+\mathrm{MM}$ in the tumor tissue and white blood cells (WBC) of patients. Our results indicated that the MU+MM genotype of the $R A R \beta 2$ gene was not correlated with breast cancer prognostic parameters in our population.

\section{Discussion}

MSP is a rapid, most widely used, and cost-effective method for gene methylation analysis [19]; however, it is not a quantitative method [20]. Hence, the results obtained in our study could be confirmed using a quantitative MSP method. However, a number of studies have 
Table 1. $R A R \beta 2$ methylation status in the blood of healthy individuals, relatives of patients, and patients

\begin{tabular}{|c|c|c|c|c|c|}
\hline $\begin{array}{l}R A R \beta 2 \\
\text { genotype }\end{array}$ & $\begin{array}{l}\text { Patients, } \mathrm{n}(\%) \\
(\mathrm{n}=102)\end{array}$ & $\begin{array}{l}\text { Relatives of } \\
\text { patients, } \mathrm{n}(\%) \\
(\mathrm{n}=102)\end{array}$ & $\begin{array}{l}\text { Healthy } \\
\text { individuals, } \\
\mathrm{n}(\%) \\
(\mathrm{n}=100)\end{array}$ & $\chi^{2}, p$ value & $\begin{array}{l}\text { Odds ratio, } 95 \% \text { confidence } \\
\text { interval, } \mathrm{p}\end{array}$ \\
\hline $\begin{array}{l}\text { UU } \\
\text { MU } \\
\text { MM }\end{array}$ & $\begin{array}{c}93(91.2) \\
7(6.9) \\
2(1.9)\end{array}$ & $\begin{array}{c}99(97.1) \\
3(2.9) \\
0(0)\end{array}$ & $\begin{array}{c}98(98) \\
2(2) \\
0(0)\end{array}$ & $7.67,0.1^{\mathrm{a}}$ & \\
\hline $\mathrm{MU}+\mathrm{MM}$ & $9(8.8)$ & $3(2.9)$ & $2(2)$ & $\begin{array}{l}4.56,0.033^{b} \\
0.18,0.66^{c}\end{array}$ & $4.7,0.99-22.5,0.05^{\mathrm{b}}$ \\
\hline
\end{tabular}

${ }^{a}$ Overall $\chi^{2}$ comparing 3 genotypes between 3 groups was $7.67, p=0.1$; overall $\chi^{2}$ comparing MU+MM versus UU genotype between 3 groups was $6.3, \mathrm{p}=0.042$.

${ }^{\mathrm{b}}$ Comparing patients and healthy individuals.

${ }^{c}$ Comparing relatives of patients and healthy individuals.

$\mathrm{UU}=$ Unmethylated; $\mathrm{MU}$ = partially methylated; $\mathrm{MM}$ = fully methylated.

suggested that MSP has a high sensitivity and specificity for the identification of breast cancer cells $[21,22]$. A frequency of $10-42 \%$ for the methylation of $R A R \beta 2$ in the promoter region of breast cancer tissue has been reported [23]. Among our studied population, the frequency of methylated RAR $\beta 2$ was found to be $18.8 \%$ in cancer tissues, which is lower than that reported for the population of Tehran (36.4\%), the capital and a cosmopolitan city of Iran [24]. However, similarity between the frequency of $R A R \beta 2$ methylation in breast cancer tissue in the present study (18.8\%) and some Asian countries such as India (15\%) [25] could be attributed to genetic admixture since the Kermanshah province is historically known as the gate of Asia through which passed the important silk road [26]. Also, the type of examined sample (blood or tissue) could be a reason for discrepancy in the reported methylation rates of $R A R \beta 2$ among various populations. The presence of discordance in the methylation status of the $R A R \beta 2$ promoter between whole blood samples and tumor tissue has been reported. Further, the frequency of hypermethylation of the gene might be ethnic-dependent. In this study, we identified a low methylation frequency of the $R A R \beta 2$ gene (2.9\%) among first-degree relatives of the patients similar to that among healthy individuals (2\%). We detected a significantly higher frequency of fully methylated $R A R \beta 2$ in cancer tissue (10.4\%) compared to matched adjacent normal breast tissue $(0 \%)(\mathrm{p}=0.02)$ and also blood of breast cancer patients $(8.8 \%)$ compared to healthy individuals (2\%), and this was associated with susceptibility to breast cancer ( $\mathrm{OR}=4.7,95 \%$ CI 0.99-22.5, $\mathrm{p}=0.05$ ).

There are controversial reports regarding the methylation rate of the $R A R \beta 2$ gene and its association with susceptibility to breast cancer among different populations (table 3). In many populations, including American [27-
Table 2. $R A R \beta 2$ methylation status in cancer and adjacent normal breast tissues and blood of patients

\begin{tabular}{|c|c|c|c|}
\hline $\begin{array}{l}R A R \beta 2 \\
\text { genotypes }\end{array}$ & $\begin{array}{l}\text { Cancer tissue, } \\
\mathrm{n}(\%) \\
(\mathrm{n}=48)\end{array}$ & $\begin{array}{l}\text { Normal tissue, } \\
\mathrm{n}(\%) \\
(\mathrm{n}=48)\end{array}$ & $\begin{array}{l}\text { Blood of } \\
\text { patients, } \mathrm{n}(\%) \\
(\mathrm{n}=48)\end{array}$ \\
\hline UU & $39(81.3)$ & 44 (91.7) & $42(87.5)$ \\
\hline MU & $4(8.3)$ & $4(8.3)$ & $4(8.3)$ \\
\hline MM & $5(10.4)$ & $0(0)$ & $\begin{array}{l}2(4.2) \\
\text { overall } \chi^{2}=5.7 \\
p=0.22^{\mathrm{a}}\end{array}$ \\
\hline $\mathrm{MU}+\mathrm{MM}$ & 9 (18.8) & $4(8.3)$ & $\begin{array}{l}6(12.5) \\
\text { overall } \chi^{2}=2.3 \\
p=0.3^{\mathrm{a}}\end{array}$ \\
\hline
\end{tabular}

${ }^{\mathrm{a}} \chi^{2}=5.3, p=0.07$ comparing 3 genotypes between breast cancer tissue and adjacent normal breast tissue; $\chi^{2}=5.3, p=0.02$ comparing $M M$ versus UU between breast cancer tissue and adjacent normal breast tissue; $\chi^{2}=1.39, \mathrm{p}=0.49$ comparing 3 genotypes between cancer tissue and blood of patients; $\chi^{2}=2.05, \mathrm{p}=0.35$ comparing 3 genotypes between normal breast tissue and blood of patients.

$\mathrm{UU}=$ Unmethylated; $\mathrm{MU}=$ partially methylated; $\mathrm{MM}=$ fully methylated.

30], Chinese [31], Indian [25], Portuguese [32], and Belgian [33], a significant association between the methylation status of the $R A R \beta 2$ gene and breast cancer incidence has been observed. Further, a meta-analysis by Fang et al. [34] reported that the methylation rate of $R A R \beta 2$ is significantly increased among breast cancer patients compared to cancer-free controls. In a report from Russia, methylated $R A R \beta 2$ was found to be 3 times more frequent in breast cancer patients than in fibroadenoma patients [35]. In contrast, a lack of association between the meth- 
Table 3. $R A R \beta 2$ methylation status and breast cancer in different populations

\begin{tabular}{|c|c|c|c|c|c|c|}
\hline Population & $\begin{array}{l}\text { Year of } \\
\text { publication }\end{array}$ & $\begin{array}{l}\text { Methylation } \\
\text { method }\end{array}$ & Specimen & $\begin{array}{l}\text { Methyl- } \\
\text { ation, \% }\end{array}$ & Main finding & Reference \\
\hline American & 2001 & MSP & $\begin{array}{l}\text { breast cancer tissue } \\
\text { white blood cells } \\
\text { normal breast tissue }\end{array}$ & $\begin{array}{r}37.5 \\
3.6 \\
0\end{array}$ & $\begin{array}{l}\text { high percent of methylated } R A R \beta 2 \\
\text { in carcinomas }(\mathrm{p}<0.01)\end{array}$ & {$[28]$} \\
\hline American & 2003 & MSP & $\begin{array}{l}\text { invasive carcinomas } \\
\text { in situ carcinomas } \\
\text { benign breast tissue }\end{array}$ & $\begin{array}{l}64 \\
60 \\
33\end{array}$ & $\begin{array}{l}\text { high frequency of methylated } \\
R A R \beta 2 \text { in both benign lesions and } \\
\text { invasive carcinomas }(p=0.05)\end{array}$ & {$[38]$} \\
\hline American & 2003 & MSP & $\begin{array}{l}\text { breast cancer tissue } \\
\text { normal breast tissue }\end{array}$ & $\begin{array}{r}46 \\
0\end{array}$ & $\begin{array}{l}\text { frequent hypermethylation in } \\
\text { breast cancer tissue compared to } \\
\text { normal tissue }(p=0.01)\end{array}$ & {$[27]$} \\
\hline American & 2005 & MSP & $\begin{array}{l}\text { breast cancer tissue } \\
\text { normal tissue of controls }\end{array}$ & $\begin{array}{r}32 \\
9\end{array}$ & $\begin{array}{l}\text { methylation of } R A R \beta 2 \text { was } \\
\text { associated with increased breast } \\
\text { cancer risk }(\mathrm{p}=0.002)\end{array}$ & [29] \\
\hline American & 2005 & MSP & $\begin{array}{l}\text { primary breast tumor } \\
\text { sentinel lymph node tumor } \\
\text { metastasis }\end{array}$ & $\begin{array}{l}24 \\
48\end{array}$ & $\begin{array}{l}\text { association of } R A R \beta 2 \\
\text { hypermethylation with } \\
\text { macroscopic SLN metastasis }(\mathrm{p}< \\
0.001)\end{array}$ & [39] \\
\hline American & 2009 & $\begin{array}{l}\text { quantitative } \\
\text { MSP }\end{array}$ & breast cancer tissue & 27.5 & $\begin{array}{l}\text { hypermethylation of } R A R \beta 2 \text { was } \\
\text { inversely associated with } \\
\text { histological grade of breast cancer } \\
(\mathrm{p}=0.13)\end{array}$ & {$[40]$} \\
\hline American & 2010 & $\begin{array}{l}\text { quantitative } \\
\text { MSP }\end{array}$ & $\begin{array}{l}\text { blood of breast cancer patients } \\
\text { blood of women with benign } \\
\text { breast disease } \\
\text { blood from healthy controls }\end{array}$ & $\begin{array}{l}6.7 \\
2.3 \\
1.1\end{array}$ & $\begin{array}{l}\text { absence of association of } R A R \beta 2 \\
\text { methylation with breast cancer } \\
\text { risk }(\mathrm{p}>0.05)\end{array}$ & {$[41]$} \\
\hline American & 2011 & $\begin{array}{l}\text { quantitative } \\
\text { MSP }\end{array}$ & breast cancer tissue & 27.5 & $\begin{array}{l}\text { absence of association between } \\
R A R \beta 2 \text { methylation status with } \\
\text { intake of vitamin B complex ( } \mathrm{p}> \\
0.05)\end{array}$ & {$[42]$} \\
\hline American & 2015 & MSP & $\begin{array}{l}\text { blood of breast cancer patients } \\
\text { breast cancer tissue } \\
\text { blood of healthy individuals }\end{array}$ & $\begin{array}{r}1.5 \\
44.5 \\
1.5\end{array}$ & $\begin{array}{l}\text { association between WBC DNA } \\
\text { methylation of the } R A R \beta 2 \text { and } \\
\text { breast cancer risk (OR: } 0.67 ; 95 \% \\
\text { CI: } 0.55-0.81 \text { ) }\end{array}$ & {$[30]$} \\
\hline Australian & 2006 & MSP & breast cancer tissue & 26 & $\begin{array}{l}R A R \beta 2 \text { methylation is linked to } \\
\text { poor histological tumor } \\
\text { differentiation }(\mathrm{p}=0.03)\end{array}$ & {$[23]$} \\
\hline Belgian & 2009 & $\begin{array}{l}\text { quantitative } \\
\text { MSP }\end{array}$ & $\begin{array}{l}\text { breast cancer tissue } \\
\text { benign breast tissue }\end{array}$ & $\begin{array}{r}29 \\
0\end{array}$ & $\begin{array}{l}\text { significantly higher frequency of } \\
\text { methylated } R A R \beta 2 \text { in } \\
\text { inflammatory }(53 \%) \text { than in non- } \\
\text { inflammatory breast cancer }(23 \%) \\
(\mathrm{p}=0.006)\end{array}$ & {$[33]$} \\
\hline Chinese & 2010 & MSP & $\begin{array}{l}\text { blood of breast cancer patients } \\
\text { blood of healthy individuals }\end{array}$ & $\begin{array}{r}42 \\
4\end{array}$ & $\begin{array}{l}\text { association of methylation status } \\
\text { of } R A R \beta 2 \text { with sporadic breast } \\
\text { cancer }(\mathrm{p}<0.05)\end{array}$ & {$[31]$} \\
\hline Egyptian & 2015 & MSP & $\begin{array}{l}\text { blood of breast cancer patients } \\
\text { blood of breast benign lesion } \\
\text { cases } \\
\text { blood of healthy subjects }\end{array}$ & $\begin{array}{r}95.9 \\
14.5 \\
0\end{array}$ & $\begin{array}{l}\text { association of } R A R \beta 2 \text { methylation } \\
\text { with breast cancer risk but not } \\
\text { with clinicopathological factors ( } \mathrm{p} \\
<0.0001 \text { ) }\end{array}$ & {$[22]$} \\
\hline Japanese & 2012 & OS-MSP & $\begin{array}{l}\text { breast cancer tissue } \\
\text { normal breast tissue }\end{array}$ & $\begin{array}{r}78 \\
0\end{array}$ & $\begin{array}{l}\text { high percentage of methylated } \\
R A R \beta 2 \text { in carcinomas (p value not } \\
\text { reported) }\end{array}$ & [43] \\
\hline
\end{tabular}


Table 3 (continued)

\begin{tabular}{|c|c|c|c|c|c|c|}
\hline Population & $\begin{array}{l}\text { Year of } \\
\text { publication }\end{array}$ & $\begin{array}{l}\text { Methylation } \\
\text { method }\end{array}$ & Specimen & $\begin{array}{l}\text { Methyl- } \\
\text { ation, \% }\end{array}$ & Main finding & Reference \\
\hline Indian & 2008 & MSP & $\begin{array}{l}\text { breast cancer tissue } \\
\text { normal breast tissues }\end{array}$ & $\begin{array}{r}15 \\
0\end{array}$ & $\begin{array}{l}\text { association of } R A R \beta 2 \text { methylation } \\
\text { with older age at onset of disease } \\
(\mathrm{p}=0.04)\end{array}$ & {$[25]$} \\
\hline Indian & 2012 & MSP & $\begin{array}{l}\text { blood of patients } \\
\text { blood of healthy women } \\
\text { breast carcinoma tissue } \\
\text { adjacent normal tissues }\end{array}$ & $\begin{array}{r}20 \\
0 \\
26 \\
6.6\end{array}$ & $\begin{array}{l}\text { absence of association between } \\
R A R-\beta 2 \text { hypermethylation and } \\
\text { loss of protein expression ( } \mathrm{p}= \\
0.70)\end{array}$ & {$[44]$} \\
\hline Iranian & 2010 & MSP & breast cancer tissue & 36.5 & $\begin{array}{l}\text { association of hypermethylated } \\
R A R \beta 2 \text { with younger age at } \\
\text { diagnosis and negative family } \\
\text { history of breast cancer }(\mathrm{p}=0.033)\end{array}$ & {$[24]$} \\
\hline Present study & & MSP & $\begin{array}{l}\text { breast cancer tissue } \\
\text { normal breast tissue } \\
\text { blood of breast cancer patients } \\
\text { blood of relatives of patients } \\
\text { blood of healthy women }\end{array}$ & $\begin{array}{c}16.3 \\
10.2 \\
8.7 \\
2.9 \\
2\end{array}$ & $\begin{array}{l}\text { significantly higher frequency of } \\
\text { methylated } R A R \beta 2 \text { in tissues and } \\
\text { blood of patients than in the blood } \\
\text { of } 2 \text { control groups }(\mathrm{p}<0.05)\end{array}$ & \\
\hline Italian & 2004 & MSP & $\begin{array}{l}\text { invasive breast tissue } \\
\text { benign breast tissue }\end{array}$ & $\begin{array}{r}20 \\
0\end{array}$ & $\begin{array}{l}\text { methylated status of } R A R \beta 2 \text { and } \\
\text { its inverse correlation with the } \\
B R C A 1 \text { promoter }(p<0.03)\end{array}$ & {$[45]$} \\
\hline Portuguese & 2008 & $\begin{array}{l}\text { quantitative } \\
\text { MSP }\end{array}$ & $\begin{array}{l}\text { breast cancer tissue } \\
\text { breast normal tissue }\end{array}$ & $\begin{array}{l}53 \\
25\end{array}$ & $\begin{array}{l}\text { significantly higher } R A R \beta 2 \\
\text { methylation percentage in breast } \\
\text { cancer tissue than in normal tissue } \\
(\mathrm{p}<0.01)\end{array}$ & {$[32]$} \\
\hline Russian & 2006 & MSP & $\begin{array}{l}\text { blood of breast cancer patients } \\
\text { blood of healthy individuals }\end{array}$ & $\begin{array}{r}15 \\
0\end{array}$ & $\begin{array}{l}R A R \beta 2 \text { methylation in circulating } \\
\text { DNA is useful for the detection of } \\
\text { malignant tumors ( } \mathrm{p} \text { value not } \\
\text { reported) }\end{array}$ & {$[21]$} \\
\hline Russian & 2008 & MSRA & $\begin{array}{l}\text { breast cancer tissue } \\
\text { breast normal tissue }\end{array}$ & $\begin{array}{r}46 \\
4\end{array}$ & $\begin{array}{l}\text { absence of association of RAR } \beta 2 \\
\text { methylation with breast cancer } \\
\text { risk }(\mathrm{p}>0.05)\end{array}$ & {$[46]$} \\
\hline Senegalese & 2006 & $\begin{array}{l}\text { quantitative } \\
\text { MSP }\end{array}$ & $\begin{array}{l}\text { blood of breast cancer patients } \\
\text { blood of healthy individuals }\end{array}$ & $\begin{array}{r}26 \\
8\end{array}$ & $\begin{array}{l}\text { absence of association of RAR } \beta 2 \\
\text { methylation with breast cancer } \\
\text { risk }(\mathrm{p}=0.09)\end{array}$ & {$[37]$} \\
\hline Tunisian & 2010 & MSP & breast cancer tissue & 66.6 & $\begin{array}{l}\text { frequent } R A R \beta 2 \text { methylation in } \\
\text { breast cancer tissue }(p=0.043)\end{array}$ & {$[35]$} \\
\hline Turkish & 2010 & $\begin{array}{l}\text { MethyLight } \\
\text { assay }\end{array}$ & $\begin{array}{l}\text { breast cancer tissue } \\
\text { adjacent normal tissue } \\
\text { blood of breast cancer patients }\end{array}$ & $\begin{array}{r}25 \\
25.9 \\
10\end{array}$ & $\begin{array}{l}\text { frequent RAR } \beta 2 \text { hypermethylation } \\
\text { in tumor and adjacent tissues }(\mathrm{p}< \\
0.05)\end{array}$ & {$[36]$} \\
\hline
\end{tabular}

MSP = Methylation-specific polymerase chain reaction; OS-MSP = one-step MSP; MSRA = enzyme-linked methylation-sensitive restriction analysis; $\mathrm{SLN}=$ sentinel lymph node; $\mathrm{WBC}=$ white blood cells.

ylation status of $R A R \beta 2$ and breast cancer risk has been reported in Russian [21], American [35], Turkish [36], and Senegalese [37] populations. Also, some studies found a lack of concordance between $R A R \beta 2$ methylation in tumor tissue and paired WBC, suggesting that there might not be a direct link between WBC gene methylation and development of breast cancer (table 3 ).

\section{Conclusion}

Our study results indicated that the presence of hypermethylation of the RAR $\beta 2$ gene in the blood of breast cancer patients was associated with susceptibility to breast cancer. This suggests that $R A R \beta 2$ hypermethylation in cancer tissue might be an epigenetic marker for 
susceptibility to breast cancer. The strength of the present research was that the $R A R \beta 2$ methylation status was studied in both the blood and tissues of patients and that methylation was further determined in relatives of the patients. Despite this strength, the low sample size of studied tissues represents a limitation of our study. Among various populations, higher frequencies of $R A R \beta 2$ methylation in breast cancer patients compared to cancer-free individuals have been reported, and in many studies, a significant association between hypermethylation of the gene and susceptibility to breast cancer has been observed. Some studies reported an association between the gene methylation rate and histological differentiation and tumor metastasis. The presence of inconsistent findings might be due to sample size, type of studied specimen (blood or tissue), breast cancer subtype, and ethnicity.

\section{Acknowledgement}

This work was performed in partial fulfillment of the requirements for PhD by Research by Mr. Kheirolah Yari, and was financially supported by a grant from the Kermanshah University of Medical Sciences Office of Vice Chancellor for Research, Kermanshah, Iran.

\section{Contribution}

K.Y. performed experiments and wrote the first draft of the manuscript. Z.R. designed the study and critically revised the manuscript.

\section{Disclosure Statement}

The authors declare no potential or actual conflicts of interest in relation to the current article.

\section{References}

1 Rahimi Z, Yari K, Rahimi Z: Matrix metalloproteinase-9-1562 $\mathrm{T}$ allele and its combination with MMP-2-735 C allele are risk factors for breast cancer. Asian Pac J Cancer Prev 2014;16:1175-1179.

2 Yari K, Rahimi Z, Payandeh M, Rahimi Z: MMP-7 A-181G polymorphism in breast cancer patients from Western Iran. Breast Care (Basel) 2015;10:398-402.

- 3 Pirouzpanah S, Taleban F-A, Mehdipour P, Atri M: Association of folate and other onecarbon related nutrients with hypermethylation status and expression of RARB, BRCA1, and RASSF1A genes in breast cancer patients. J Mol Med (Berl) 2015;93:917-934.

4 Yari K, Payandeh M, Rahimi Z: Association of the hypermethylation status of PTEN tumor suppressor gene with the risk of breast cancer among Kurdish population from Western Iran. Tumour Biol 2016;37:8145-8152.

$\checkmark 5$ Marzese DM, Hoon DS, Chong KK, et al: DNA methylation index and methylation profile of invasive ductal breast tumors. J Mol Diagn 2012;14:613-622.

6 Lubecka-Pietruszewska K, Kaufman-Szymczyk A, Stefanska B, Fabianowska-Majewska K: Folic acid enforces DNA methylation-mediated transcriptional silencing of PTEN, APC and RARbeta2 tumour suppressor genes in breast cancer. Biochem Biophys Res Commun 2013;430:623-628.

7 Moison C, Senamaud-Beaufort C, Fourrière $\mathrm{L}$, et al: DNA methylation associated with polycomb repression in retinoic acid receptor $\beta$ silencing. FASEB J 2013;27:1468-1478.

${ }_{8}$ Sirchia SM, Ferguson AT, Sironi E, et al: Evidence of epigenetic changes affecting the chromatin state of the retinoic acid receptor beta2 promoter in breast cancer cells. Oncogene 2000;19:1556-1563.

-9 Ivanova T, Petrenko A, Gritsko T, et al: Methylation and silencing of the retinoic acid receptor- $\beta 2$ gene in cervical cancer. BMC Cancer 2002;2:4.
10 Wongwarangkana C, Wanlapakorn N, Chansaenroj J, Poovorawan Y: Retinoic acid receptor beta promoter methylation and risk of cervical cancer. World J Virol 2018;7:1.

11 Xu X-C, Ro JY, Lee JS, et al: Differential expression of nuclear retinoid receptors in normal, premalignant, and malignant head and neck tissues. Cancer Res 1994;54:3580-3587.

12 Li Y, Lu DG, Ma YM, Liu H: Association between retinoic acid receptor- $\beta$ hypermethylation and NSCLC risk: a meta-analysis and literature review. Oncotarget 2017;8:5814.

13 Dou M, Zhou X, Fan Z, et al: Clinical significance of retinoic acid receptor beta promoter methylation in prostate cancer: a meta-analysis. Cell Physiol Biochem 2018;45:2497-2505.

14 Klajic J, Fleischer T, Dejeux E, et al: Quantitative DNA methylation analyses reveal stage dependent DNA methylation and association to clinico-pathological factors in breast tumors. BMC Cancer 2013;13:456.

15 Sadeq V, Isar N, Manoochehr T: Association of sporadic breast cancer with PTEN/ MMAC1/TEP1 promoter hypermethylation. Med Oncol 2011;28:420-423.

16 Hashemi M, Rezaei H, Eskandari-Nasab E, Kaykhaei M-A, Taheri M: Association of promoter methylation and 32-bp deletion of the PTEN gene with susceptibility to metabolic syndrome. Mol Med Rep 2013;7:342-346.

17 Conway K, Edmiston SN, May R, et al: DNA methylation profiling in the Carolina Breast Cancer Study defines cancer subclasses differing in clinicopathologic characteristics and survival. Breast Cancer Res 2014;16:450.

18 Yari K, Rahimi Z, Moradi MT, Rahimi Z: The MMP-2-35 C allele is a risk factor for susceptibility to breast cancer. Asian Pac J Cancer Prev 2013;15:6199-6203.

19 Licchesi JD, Herman JG: Methylation-specific PCR; in Jörg Tost (ed): DNA Methylation. Berlin, Springer, 2009, pp 305-323.
20 Shen L, Waterland RA: Methods of DNA methylation analysis. Curr Opin Clin Nutr Metab Care 2007; 10:576-581.

21 Skvortsova T, Rykova E, Tamkovich S, et al: Cell-free and cell-bound circulating DNA in breast tumours: DNA quantification and analysis of tumour-related gene methylation. Brit J Cancer 2006;94:1492-1495.

22 Swellam M, Abdelmaksoud MD, Sayed Mahmoud M, et al: Aberrant methylation of APC and RAR $\beta 2$ genes in breast cancer patients. IUBMB Life 2015;67:61-68.

23 Li S, Rong M, Iacopetta B: DNA hypermethylation in breast cancer and its association with clinicopathological features. Cancer Lett 2006;237:272-280.

24 Pirouzpanah S, Taleban FA, Atri M, Abadi A-R, Mehdipour P: The effect of modifiable potentials on hypermethylation status of retinoic acid receptor-beta2 and estrogen receptor-alpha genes in primary breast cancer. Cancer Causes Control 2010;21:2101-2111.

25 Bagadi SAR, Prasad CP, Kaur J, et al: Clinical significance of promoter hypermethylation of RASSF1A, RAR 32 , BRCA1 and HOXA5 in breast cancers of Indian patients. Life Sci 2008;82:1288-1292.

26 Rahimi Z, Akramipour R, Nagel RL, et al: The $\beta$-globin gene haplotypes associated with $\mathrm{Hb}$ D-Los Angeles ( $\beta 121(\mathrm{GH} 4) \mathrm{Glu} \rightarrow \mathrm{Gln})$ in western Iran. Hemoglobin 2006;30:39-44.

27 Fackler MJ, McVeigh M, Evron E, et al: DNA methylation of RASSF1A, HIN-1, RAR- $\beta$, Cyclin D2 and Twist in in situ and invasive lobular breast carcinoma. Int J Cancer 2003;107: 970-975.

28 Evron E, Dooley WC, Umbricht CB, et al: Detection of breast cancer cells in ductal lavage fluid by methylation-specific PCR. Lancet 2001;357:1335-1336.

29 Lewis CM, Cler LR, Bu D-W, et al: Promoter hypermethylation in benign breast epithelium in relation to predicted breast cancer risk. Clin Cancer Res 2005;11:166-172. 
30 Cho YH, McCullough LE, Gammon MD, et al: Promoter hypermethylation in white blood cell DNA and breast cancer risk. J Cancer 2015;6:819.

-31 Jing F, Yuping W, Yong C, et al: CpG island methylator phenotype of multigene in serum of sporadic breast carcinoma. Tumor Biol 2010;31:321-331.

-32 Jeronimo C, Monteiro P, Henrique R, et al: Quantitative hypermethylation of a small panel of genes augments the diagnostic accuracy in fine-needle aspirate washings of breast lesions. Breast Cancer Res Treat 2008;109:27-34.

\33 Van der Auwera I, Bovie C, Svensson C, et al: Quantitative assessment of DNA hypermethylation in the inflammatory and non-inflammatory breast cancer phenotypes. Cancer Biol Ther 2009;8:2252-2259.

34 Fang C, Jian Z-Y, Shen X-F, et al: Promoter methylation of the retinoic acid receptor beta2 (RAR 32$)$ is associated with increased risk of breast cancer: a PRISMA compliant meta-analysis. PLoS One 2015;10:e0140329.

35 Karray-Chouayekh S, Trifa F, Khabir A, et al: Aberrant methylation of RASSF1A is associated with poor survival in Tunisian breast cancer patients. J Cancer Res Clin Oncol 2010;136:203-210.
36 Cho YH, Yazici H, Wu H-C, et al: Aberrant promoter hypermethylation and genomic hypomethylation in tumor, adjacent normal tissues and blood from breast cancer patients. Anticancer Res 2010;30:2489-2496.

37 Hoque MO, Feng Q, Toure P, et al: Detection of aberrant methylation of four genes in plasma DNA for the detection of breast cancer. J Clin Oncol 2006;24:4262-4269.

38 Pu RT, Laitala LE, Alli PM, et al: Methylation profiling of benign and malignant breast lesions and its application to cytopathology. Modern Pathol 2003;16:1095-1101.

39 Shinozaki M, Hoon DS, Giuliano AE, et al: Distinct hypermethylation profile of primary breast cancer is associated with sentinel lymph node metastasis. Clin Cancer Res 2005; 11:2156-2162.

40 Tao MH, Shields PG, Nie J, et al: DNA hypermethylation and clinicopathological features in breast cancer: the Western New York Exposures and Breast Cancer (WEB) Study. Breast Cancer Res Treat 2009;114:559-568.

41 Brooks JD, Cairns P, Shore RE, et al: DNA methylation in pre-diagnostic serum samples of breast cancer cases: results of a nested casecontrol study. Cancer Epidemiol 2010;34: 717-723.
42 Tao M-H, Mason JB, Marian C, et al: Promoter methylation of E-cadherin, p16, and RAR- $\beta 2$ genes in breast tumors and dietary intake of nutrients important in one-carbon metabolism. Nutr Cancer 2011;63:11431150.

43 Yamamoto N, Nakayama T, Kajita M, et al: Detection of aberrant promoter methylation of GSTP1, RASSF1A, and RAR $\beta 2$ in serum DNA of patients with breast cancer by a newly established one-step methylation-specific PCR assay. Breast Cancer Res Treat 2012;132: 165-173.

44 Mirza S, Sharma G, Parshad R, et al: Clinical significance of Stratifin, ERa and PR promoter methylation in tumor and serum DNA in Indian breast cancer patients. Clin Biochem 2010;43:380-386.

45 Parrella P, Poeta ML, Gallo AP, et al: Nonrandom distribution of aberrant promoter methylation of cancer-related genes in sporadic breast tumors. Clin Cancer Res 2004;10: 5349-5354.

46 Khodyrev D, Loginov V, Pronina I, et al: Methylation of promoter region of RAR- $\beta 2$ gene in renal cell, breast, and ovarian carcinomas. Russ J Genet 2008;44:983-988. 